IMR

38,1

Received 31 January 2019 Revised 1 October 2019 Accepted 14 November 2019

\section{Nation branding, cultural identity and political polarization - an exploratory framework}

\author{
Alessandra Vecchi \\ School of Management, Universita degli Studi di Bologna, Bologna, Italy \\ Emmanuel Sirimal Silva \\ Centre for Fashion Business \& Innovation Research, Fashion Business School, \\ London College of Fashion, University of the Arts London, London, UK, and \\ Lina Maria Jimenez Angel \\ Griffith College Dublin, Dublin, Ireland
}

\begin{abstract}
Purpose - The objective of this research is to propose a framework which is apt to assess how a nation branding campaign could promote cultural identity by ultimately curbing political polarization.

Design/methodology/approach - By relying on a multidisciplinary approach that blends theoretical constructs from different fields the methodology is based on a mixed-method approach whereby the qualitative data stemming from a set of interviews with key-informants is coupled by a survey of Colombian citizens in order to gain in-depth insights over the impact of nation branding on political polarization.

Findings - From the findings, it emerges that a campaign based on nation branding and targeting domestic citizens could curb political polarization within Colombia, by also fostering cultural identity.

Research limitations/implications - The study considers only Colombia. To fully assess the robustness of the framework it would be useful to extend the analysis to a broader range of countries and to a wider set of domestic issues.

Practical implications - The research not only provides in-depth insights on how nation branding can be used effectively in order to curb political polarization but also practical guidance on how a nation branding campaign can be effectively designed. The findings are relevant to policy-makers that have the opportunity to implement informed and educated nation branding campaigns not just overseas, but also to strategically address important domestic issues by engaging the domestic stakeholders.

Originality/value - While country branding has been extensively investigated within the context of international business, we have a relatively limited understanding of its domestic impact. In contrast to traditional country branding literature, this paper aims to theoretically advance our understanding of nation branding and its effect on political polarization, as well as gauging its impact on cultural identity.
\end{abstract}

Keywords Nation branding, Country branding, Cultural identity, Polarization, Colombia

Paper type Research paper

\section{Introduction}

In November 2016 the Colombian government and the Revolutionary Armed Forces of Colombia (FARC) signed a peace agreement with the objective of ending crimes against humanity and drug trafficking activities, in exchange of forgiveness for some of them, and the opportunity to be part of the politic arena (OACP, 2017). Even though all the efforts were aimed at bringing peace to a country that was suffering the horror of terrorism for more than half-century, a visible form of political polarization and the emergence of ideological extremes

(C) Alessandra Vecchi, Emmanuel Sirimal Silva and Lina Maria Jimenez Angel. Published by Emerald Publishing Limited. This article is published under the Creative Commons Attribution (CC BY 4.0) licence. Anyone may reproduce, distribute, translate and create derivative works of this article (for both commercial and non-commercial purposes), subject to full attribution to the original publication and authors. The full terms of this licence may be seen at http://creativecommons.org/licences/by/4.0/ legalcode
International Marketing Review Vol. 38 No. 1, 2021 pp. $70-98$

Emerald Publishing Limited 0265-1335

DOI 10.1108/IMR-01-2019-0049 
emerged, and nowadays not just politicians are taking extreme sides and radical ideas, but also Colombian citizens are involved in endless discussions around peace (EAFIT, 2017). Now, the country is going through the post-conflict stage and is facing several challenges as the implementation of the Special Jurisdiction for Peace (JEP), whose main objective is to provide compensation to the victims of the conflict and to judge those who committed crimes (JEP, 2017). Likewise, another major challenge were the presidential elections on 2018 where politicians were opportunistic taking 'peace' as a topic for campaigns to gain votes (Tiempo, 2017) bringing about more polarization between people and consequently, division. Colombia without a doubt is living a historical moment and a transitional period, yet their people are more divided than ever. Hence, in this 'new era' where Colombia is experiencing one of the most important moments of its history, how could this be different? How could this feeling of anger and radical division be transformed into something positive?.

Starting from these facts, in contrast to traditional country branding that focuses on destination, tourism marketing, and the country-of-origin effect, this paper aims to theoretically advance our understanding of nation branding and to critically gauge its effect on political polarization, as well as examining its potential influence on cultural identity. To this purpose, the paper proposes a framework which is apt to assess how a nation branding campaign could foster cultural identity amongst the Colombian citizens and could also change their attitudes and behaviours related to political polarization in Colombia. The paper comprises five sections. The second section, in a multidisciplinary fashion, reviews the relevant literature on political polarization and country branding to provide the foundations for the conceptual framework. The third section outlines the methodology adopted. While the fourth section presents the main findings, the concluding section addresses the main contribution of the research, the limitations of its findings, their implications as well as directions for future research.

\section{Literature review}

\subsection{Political polarization}

Polarized societies are those where differences within the country are reinforced in two or more groups. Commonly, these groups describe themselves as 'us' and the others as 'them' (Somer and McCoy, 2018). A clear example of this is how nowadays in the United States people tend to identify themselves in two main groups: the real Americans or the immigrants (Somer and McCoy, 2018). Therefore, societies begin to be divided by taking strong political ideas in their own groups, and also people acquire specific social identities (McCoy's et al., 2018). Likewise, when language itself starts to change in the way of 'us' and 'them' social exclusion becomes stronger, and politics start to be polarized across recognisable groups (McCoy's et al., 2018).

Yang et al. (2016) argue that polarization in countries appears when an individual starts to perceive differences with their political opponents with regard to values and goals. However, in highly polarized nations individuals are pushed to choose a side, or be categorised by others as people that belong to a specific group (McCoy's et al., 2018). Overall, scholars who engage in the political polarization debate tend to argue that while political elites and party activists are increasingly polarized, ordinary citizens are not (Baldassarri and Bearman, 2007).

This is not the case of Colombia, where people at the second round of the presidential elections of 2018 were pushed to vote for one of the two candidates and where the no-vote was frowned upon (Molano and García, 2018) by therefore causing more polarization and dragging people to join one of the two groups. Therefore, state of crisis (Handlin, 2018), democracy collapse and politics generate political polarization (Stavrakakis, 2018). What happened in the United Kingdom with Brexit, in Colombia with the peace referendum, in France and Austria with the victory of populist leaders? All of these cases are the reflection of politically polarized countries (McCoy's et al., 2018). Likewise, polarization is not directly related to any particular political group, it is not a phenomenon which could be identified in countries where the left-wing is in the power or the opposite. For instance, Turkey and

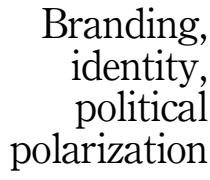


IMR 38,1

Venezuela where the power is highly concentrated polarization is evident. On the contrary, paralysed systems as in the United States with a populist leader demonstrate how polarization could affect any society (McCoy's et al., 2018).

Finally, politics plays a key role in polarization, it is relevant to highlight that politicians build strategies to manipulate participatory mechanisms such as elections, to weaken institutions, and to undermine their political opponents (Somer and McCoy, 2018) dividing society into different and inflexible blocks. 'Divide et impera' or divide and conquer is not a new strategy in politics. The maxim 'divide et impera' has been attributed to Philip II of Macedon, and with 'divide ut regnes' was utilised by Caesar and by Napoleon. Traiano Boccalini cites 'divide et impera' as a common principle in politics. The use of this strategy is meant to empower the sovereign to control populations, or factions of different interests, who collectively might be able to oppose his rule. Machiavelli identifies a similar application to military strategy, advising in The Art of War that a captain should endeavour with every art to divide the forces of the enemy, either by making him suspicious of his men in whom he trusted, or by giving him cause that he has to separate his forces, and, because of this, become weaker.

Political polarization can be seen as a form of democratic decay according to Somer and McCoy (2018). Political elites and institutions cannot respond to social demands causing division and inequality. This type of political polarization is 'bottom-up polarization' as it comes from the citizens instead of the political leaders. Internal tensions, disagreements and conflicts can generate polarization in a country. Encounters between different political groups that have different opinions and ideas, who are expecting different outcomes from democracy could trigger this phenomenon. Somer and McCoy (2018) highlight that nowadays many democracies are polarized because of democratic crisis where politicians try unsuccessfully to reform laws and institutions. The case of Colombia could be framed into this category since the peace referendum generated a democratic crisis which caused a clear polarized society (Cortés, 2018). Likewise, Stavrakakis (2018) argues that polarized democracies are in the need of renewing their symbols and values in order to restore the order.

Polarization can help to build political parties, and to foster mobilization consolidating the political systems (Somer and McCoy, 2018). Furthermore, a moderate polarization is necessary within a pluralist democratic system because it allows balancing forces within a state (Stavrakakis, 2018). Thus, even though excessive polarization can be extremely harmful in a country, in some cases it is helpful to enhance democracy.

Finally, it is relevant to outline that high polarization is often associated with political gridlock (Duhaime and Apfelbaum, 2017), and Handlin (2018) also recognizes when an outsider politician unexpectedly gains power, this could also lead to excessive levels of polarization.

\subsection{Polarization and selective media exposure}

Media exposure plays a pivotal role in fostering political polarization (Prior, 2013). Nowadays, there are plenty of channels with diversified content creating a very complex environment (Yang et al., 2016) where people can be informed almost about everything in the moment they prefer. In polarized societies citizens choose the content and news they want to consume, this content tends be aligned with their beliefs and political thoughts (Morris, 2007). People avoid any subject that tends to be different from their point of view and that could challenge their own positions (Spohr, 2017; Kim, 2015). This tendency of choosing specific information that is aligned to our own credo is called selective exposure and it is increasing exponentially due to the ever-growing variety of the media channels available (Spohr, 2017; Kim, 2015). In the United States for example there is evidence that Republicans prefer to watch Fox News, and Democrats prefer CNN and NPR. Both of them avoiding the opposite channel (Kim, 2015).

Media trigger different behaviours in polarized societies. For instance, people tend to judge the ones who think differently. Furthermore, media shapes perspectives, positions regarding specific issues, and affects minds deeply (Yang et al., 2016). Besides, partisan media 
the ones which are not objective, usually deliver exaggerate information against the opposition and regularly tell their audience that 'the others' have extreme positions regarding politics (Yang et al., 2016).

Consumption of news and content is increasingly taking place on the Internet, where polarization starts to be more evident (Spohr, 2017). In accordance with Lee (2016) in his study Impact of Social Media on Opinion Polarization in Varying Times the more heterogeneous is the media network, the higher level of polarization since people who are politically engaged take and reinforce information which is going in the same path as their opinions. Moreover, Lee claims that when citizens have a wide media environment, polarization will increase strengthening opinions and attitudes.

On the other hand, social media has a considerable role in polarization. The reason behind this relevance is because social networks give the possibility for citizens to express their ideas and opinions. It allows people to be engaged in fierce political discussions. Conversely, Yang et al. (2016) suggest that the online environment increase polarization since social media allows people to discuss, and also these kind of digital platforms shows likeminded information to users, reinforcing their own beliefs, and being exposed to biased content (Duhaime and Apfelbaum, 2017). In the same way, Lee affirms that people are consuming one side of the content (2016). Thus, selective exposure generates intolerance since when people are bared to just one side of the information they become less tolerant to different perspectives and opinions (Kim, 2015).

Finally, even though fake news are not the principal cause of polarization, it has enormous consequences as people involved in political discussions tend to read likeminded information and to share it, thus fake news become part of arguments and also political strategies (Spohr, 2017).

Polarization is usually measured in terms of the attitudes and distance between political parties, elites, electorate and society (McCoy's et al., 2018). South America has experienced a rising of populist parties that have brought polarization. These leaders describe themselves as saviours, and throughout a populist speech they persuade their electorate (Santander et al., 2017).

Handlin (2018) claims that, Colombia was within the top 5 of polarized countries in South America between 2010 and 2011 after Ecuador, Venezuela, Bolivia and Chile. Nonetheless, from the peace agreement until the present days, Colombia has faced a strong political polarization. The presidential elections in 2018 has increased this phenomenon inside the country (La Nación, 2018) and it is believed that it could be decreased because so far it is not as high and harmful than other countries in the region as Venezuela (Semana, 2017).

In a similar way, Jorge Cortés (2018) expresses his view that the peace referendum left a polarized country which got worst during the elections. Families and friends were divided around this subject, and even Twitter became a media which contributed to polarization (Cortés, 2018; Hernández, 2018).

Finally, nowadays Colombians are polarized on two sides: one is called democratic security (right-wing), and the other side is the one closer to communism (Santander et al., 2017). Both sides are perceived by their opposites as the worst path for the country by therefore generating further polarization, discussions, disunion and crisis in the Colombian society.

\subsection{The power of branding in societies}

Polarization, as it was discussed above, has pernicious consequences in societies, and provides an interesting setting where country branding could play a pivotal role. Branding has indeed a remarkable impact not only consumer behaviour but also on societies at large (Suarez and Belk, 2017). Anholt (2005) defines branding as all the elements which allow a product, company or service to have an identity and be recognised. Even though this

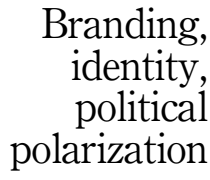

73 
IMR

38,1

definition seems simple many theories and academic studies have arisen throughout history showing how powerful branding can be within different societies and cultures. Some of these investigations claim that iconic brands should build myths to remain memorable, others affirm that brands are cultural forms and are an important part of the community, and some of them say that brands are assets of societies (Holt, 2003; Schroeder, 2009; Askegaard, 2006; Cayla and Arnould, 2008).

Holt (2003) for instance outlines how the most important global brands such as Coca-Cola, Mountain Dew, Adidas and Apple became iconic by being able to create myths through advertising by give their consumers a sense of the world generating aspirational ways of living. When a brand creates powerful myths it becomes iconic and this could happen only when it is able to understand the culture and also to adapt when society evolves, ergo be ready for cultural disruptions.

Cayla and Arnould (2008) propose a cultural approach of branding where brands do not have to be considered just as myths, but also as global symbols that are allocated in a system. Therefore, the meaning of brands comes from oppositions, for instance, Apple is what it is because it is not IBM nor Lenovo. Thus, their proposal is based on the extension of the myths approach, giving sense to brands through symbols and systems.

Furthermore, following the perspective of Cayla and Arnould, Schroeder (2009) claims that: "Brands are not only mediators of cultural meaning - brands themselves have become ideological referents that shape cultural rituals, economic activities, and social norms' (Schroeder, 2009, p. 124).

Within this context, strong brands are creating messages that take into account the way we interact with others, the mode we talk, our specific likes and dislikes, Thus, marketers have to be close to religion, education, economy, politics and social media, to be able to understand societies. Moreover, brand culture brings to the table the undeniable relation between brand identity and consumer understanding and the need to connect with the culture (Schroeder, 2009).

2.3.1 Understanding citizens in open contexts. Brands are part of the culture. However, it is pertinent to recognize the role of the consumer which is an active actor in the process of branding. Consumers are not naïve individuals whereby companies cannot offer a product without thinking about the user and their needs (Roubal, 2017). Increasingly marketing activity is dedicated to monitoring the consumer, their reactions, and with digital tools, this task has become more efficient. For that reason, Banerjee affirms that acknowledging consumer behaviour in the global marketplace is basic to brands, and also in order to succeed in a certain country it is completely necessary to know beliefs, behaviour, values, etc. (Banerjee, 2008).

Thus, consumers are now co-creators of the brands, so in that way, they are producing value on it. People are active, so day-to-day consumers are confirming their values and practices, becoming a rich source of brands. Therefore, according to Roubal (2017), brands should communicate through open contexts instead of closed systems because messages under an open context are focused on 'you may' not on 'you must', and when branding achieves this, it is likely that consumers start to identify with brands and be emotionally connected (2017). Also, the concept of 'brand-culture fit' is linked to the idea that it is necessary to be close to consumers to identify their cultural heritage in order to be accepted (Banerjee, 2008).

Moreover, Roubal (2017) identifies three elements that consumers should experience in the branding process, and it highlights the importance of having open systems where consumers should have an active role in this process. Hence, the first step is to identify what factors induce consumers to engage in self-reflection because brands cannot act by themselves, they must consider their audience thoughts and insights. Then, the process concludes with selfrecognition and confirmation which is the ideal situation when a brand reaches a customer. 
In order to generate value for the brands, companies use different methods to know consumers beforehand, and during the communication process. They need to know their thoughts and perceptions in relation to a specific product or service. For instance, techniques as field observation, networks analysis, reports to identify customers' experience, allow brands to better understand the culture and also to be closer to people (Roubal, 2017).

Adding value to brands occurs in both ways, but reaching the consumer is the hardest part. For that reason, communicating in open contexts with positive and aspirational messages is a key strategic point in marketing (Roubal, 2017). For instance, Nike campaigns are going deep into the consumer culture giving a clear and strong message: 'Just do it'. This brand goes beyond the product, they want followers and loyal devotees more than mere customers. Nike understands subcultures, they do the work to interpret society. For that reason, Nike is not just a profitable and successful company, it is also a brand where customers feel self-confirmation.

Consequently, building durable bonds with customers is one of the main objectives of branding, for that reason Banerjee (2008) proposes the 'brand culture framework' where brand heritage and cultural heritage are the main pillars. The first one refers to the elements directly related with the brand history (the past of the brand), its image (the opinion in the mind of the consumers related to the brand), its expectancy (benefits offered by the brand) and equity (all the elements belonging to the brand). The second one refers to the elements identified in a society such as beliefs, norms, laws and social behaviours (Banerjee, 2008).

\subsection{Country branding}

Having analysed branding as a powerful way to change behaviours and societies, now the concept of country branding will be presented in order to explain how a nation manages its image overseas, with which purposes, and also this perspective will lay down the main foundations of our framework. Globalization is turning the world into a gigantic supermarket where countries need to compete to stimulate exports, attract tourism, foreign direct investments and immigration (Fetscherin, 2010). Despite an increasing number of articles dedicated to the topic, there is still no a commonly shared definition of a country brand. Fan (2006, p. 8) makes an early attempt at defining it as 'a country's whole image, covering political, economic, historical and cultural dimensions. The concept is at the national level, multidimensional and context dependent'. Dinnie (2005, p. 15) defines country brand as 'the unique, multi-dimensional blend of elements that provide the nation with culturally grounded differentiation and relevance for all of its target audiences'. Aronczyk (2008, p. 42) states that a country brand should 'attract the "right" kinds of investment, tourism, trade, and talent'. Kotler et al. (1993) as well as Rawson (2007) argue that governments should create, promote, protect, and supervise a country's brand. Fetscherin (2010, pp. 467-468) claims that 'a country brand belongs to the public domain; it is complex and includes multiple levels, components, and disciplines. It entails the collective involvement of the many stakeholders it must appeal to. It concerns a country's whole image, covering political, economic, social, environmental, historical, and cultural aspects. The main objectives of country branding are to stimulate exports, attract tourism, investments, and immigration, and create positive international perceptions and attitudes'. More broadly country branding could be defined as all the activities a country does in order to foster tourism, investment, economy and to enhance the reputation of a nation (Che-Ha et al., 2016).

In recent times there has been a growing trend among countries to aggressively build, improve and promote their national image (He and Wang, 2015). Research on the country-oforigin effect has decomposed the construct into product and country image (Li et al., 2014; Wang et al., 2012). In particular the latter refers to the mental representation of a country and its people, including cognitive believes of the country's economic and technological

\section{Branding, identity, political polarization}

75 
IMR 38,1

development stages, as well as affective evaluations of its social and political systems or standpoints (Li et al., 2014; Wang et al., 2012). The country of origin image, or country image, is used in the literature to refer either to a set of country of origin associations organized into groups in a meaningful way (Kotler et al., 1993), or to all the beliefs that one has about a particular country (Martin and Eroglu, 1993). To this end, stereotypes are often used to influence country perceptions (Chattalas et al., 2008). An advertising campaign for Singapore Airlines stated, 'In this ever changing world, Singapore Girl, you're a great way to fly', reintroducing the warm and 'Singapore Girl' to a more contemporary audience. This advertising campaign, positioning Singapore as a relatively warm, tender and friendly nation, exemplifies the use of national stereotype dimensions to influence country perceptions in marketing practice. Stereotypes represent individuals' cognitive associations and expectations about any societal group (Fiske and Taylor, 1991), while national stereotypes are qualities perceived to be associated with a nation's citizens (Schneider, 2005). Building and maintaining a strong nation brand is of pivotal importance to emerging market firms, as their products and brands often suffer from the so-called 'liability of emergingness' (Held and Berg, 2015).

Fan in the article Branding the Nation: What is being branded? (2006) begins the study by clarifying the difference between nation branding and nation brand. Claiming that the former refers to the complete image around a country, including politics, economics, culture and history; whereas the latter denotes activities done for companies that want to exploit the name of the country, without any control from official institutions (Fan, 2006). Herstein (2012) proposes a model of branding a country through a particular positioning, which allows marketers to choose the most suitable strategy to make it more attractive for touristic purposes. This study shows how a mix of marketing tools could be useful in the countrybranding arena. The author's framework is based on the culture and the geography of a country. By applying a company-based brand equity approach, Fetscherin (2010) presents a standardized Country Brand Strength Index (CBSI).

Lastly, according to Kilduff and Núñez-Tabales (2014) country branding is performed in order to improve and attract trade and foreign investment, also to promote tourism and to generate awareness of the country. Likewise, it is demonstrated that nation branding enhances the image of countries (Blain et al., 2005). The literature on country image has been extensively used to analyse consumers' responses (beliefs, attitudes and intentions) toward foreign products and services (Pharr, 2005). In particular, this theoretical framework has been mainly applied to tangible products, and to target external stakeholders such as investors, customers and so on.

The big majority of these studies mostly addresses the effect on branding on external stakeholders. However, country branding could be also used to engage some internal stakeholders. Vasudevan (2008), for instance argues that internal branding for a place is a tough objective, given that most place brands are created with the external audience in mind. The people of a place are under no compulsion to internalise the brand. The case study of Kerala Tourism offers an insight into the different internal audiences in case of a place brand, and what branding initiatives mean to them.

Similarly, Kemp et al. (2012), claim that an important part of building a successful branding strategy for a city or region is examining the needs of internal stakeholders. Their study provides evidence that stakeholder buy-in is important in the brand-building process. Their research demonstrates that marketing programs can create positive attitudes in residents toward a destination's brand and subsequently lead to residents that are committed to the branding efforts of a destination. Similarly, Morgan et al. (2012) develop a new destination management organization marketing evaluation framework by using the case of 'Visit Wales' whereby they outline the strategic importance of the internal stakeholders that need to be proactively engaged in advocacy for the country branding campaign to be successful. 
More specifically in relation to internal country branding targeting citizens, Che-Ha et al. (2016) demonstrate how country branding should be conducted first with their citizens and then overseas in order to generate positive emotions in people. Hence, this study supports the initial premise about the relevance of doing country branding inside the nation. The authors propose country branding as a mixture of several elements in order to gain competitive advantage and to shape citizens emotions. The framework is depicted in Figure 1.

Skinner and Kubacki (2007) take this argument even further and attempt to unravel the complex relationship between nationhood, national and cultural identity, and a place's brand identity by means of a literature review that examines these concepts from a wide range of disciplines. The result is an original model that conceptualises the nation brand identity as a whole, identifies both what affects the nation brand and what is affected by the nation brand, and how the nation brand identity is created and communicated. From their findings it emerges that when attempting to unravel the complex relationship between nationhood, cultural identity and place branding, there are factors wider than culture production that can inform the debate, not least of which is the confusion over what constitutes a nation with perspectives viewing a nation either as a political entity, a cultural entity or a fusion of the two. The wider literature acknowledges the importance not just of cultural and political systems but also of economic and legal systems along with the technical forces and other macro environmental factors that impact on a nation. The literature also contains many examples of regions, cities and suburbs that have applied principles of place branding to positive effect. The model therefore shows the impact of a nation's own political, cultural, economic and legal systems on the sub-national places within the nation. According to the authors, these places may also be branded, reflecting the view identified in the literature of the nation as corporate brand.

Although Anholt (2005; p. 28) suggested that "nation branding is (...) a task infinitely larger and more complex than anything which marketing services agencies have ever had to tackle before', there is a vast emblematic evidence that shows that nation branding has already become a professional and very well-organised part of the marketing industry. Studies have also been undertaken into the way in which nations, such as Ireland, have refashioned their identities (Miley, 2013), with similar issues facing Spain (Gilmore, 2002; Olins, 2002). Furthermore, studies have also been undertaken on the brand identities of nations such as America (Dinnie, 2005), Armenia (Pant, 2005), India (Kerrigan et al., 2012), New Zealand (Morgan et al., 2002; Lodge, 2002), Nigeria (Viosca et al., 2004), Poland (Florek, 2005; Kubacki and Skinner, 2006), Singapore (Haley and Low, 1998), Taiwan (Amine

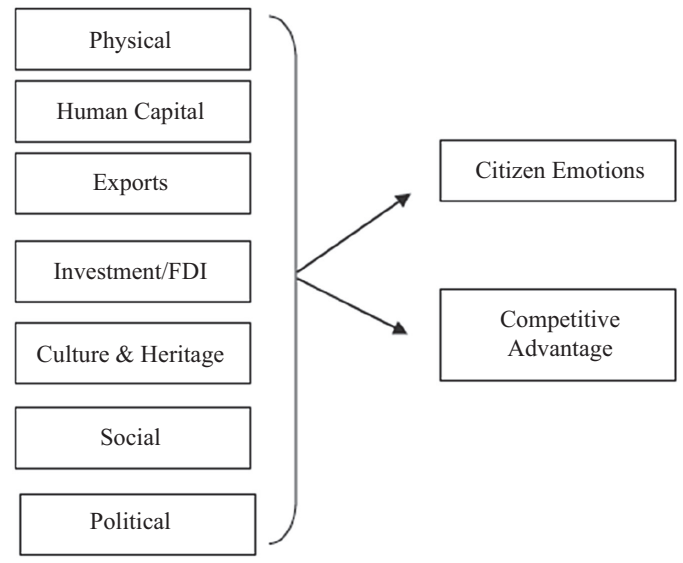

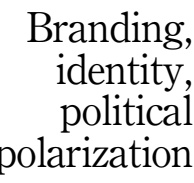

Figure 1.

Country branding framework (adapted from Che-Ha et al., 2016) 
IMR

38,1

78

and Chao, 2005) and Wales (Pride, 2002; Skinner and Croft, 2004). Romania and Estonia have done efforts to brand the nation, however, some negative perceptions towards these places remain the same. The lack of market research and knowledge of the audience are likely the cause of this failure (Prelipceanu, 2015; Same and Solarte-Vasquez, 2014).

Finally, country branding is a useful tool which nowadays nations are taking advantage of to increase their awareness overseas in order to generate different outcomes (Vasudevan, 2008; Kemp et al., 2012; Morgan et al., 2012; Che-Ha et al., 2016). In the specific case of Colombia, the brand 'Colombia Co' is the one that has been used to promote the country abroad (Colombia Co, 2018). Nonetheless, this brand has not been leveraged internally yet to target its citizens, by thus providing a strong rationale to assess the potential impact of a nation branding campaign inside Colombia.

\subsection{Conceptual framework}

The main purpose of this study is to propose a framework which is apt to assess how marketing and advertising techniques could change behaviours related to political polarization in Colombia encouraging citizens to be united and to behave against polarization, hate and division. Thus, the framework proposed is shown in Figure 2.

By drawing on the relevant literature, the framework proposed for the research is depicted in Figure 2. It outlines the causes and consequences of polarization in Colombia and it shows the solution suggested which is a long-term country-branding campaign targeting its domestic citizens. Within this context nation branding could bring different advantages, as the possibility of changing attitudes and behaviours (Holt, 2003; Cayla and Arnould, 2008; Schroeder, 2009), shaping cultural identity (Askegaard, 2006; Skinner and Kubacki, 2007; Schroeder, 2009), and to create an iconic brand (Holt, 2003). When the culture and the audience is understood as open contexts by considering the citizens as an active part of the branding process, this may generate self-reflection, self-recognition and self-confirmation between the country brand and the receptor of the message (Roubal, 2017). Consequently, the outcome would be a heightened sense of cultural identity (Skinner and Kubacki, 2007) and decreased polarization (Spohr, 2017). It is important to highlight that the message should be compelling and evocative enough to mobilize self-reflection, self-recognition and self-confirmation by ultimately shaping cultural identity and curbing political polarization.

Figure 2.

Conceptual framework (authors' own elaboration)

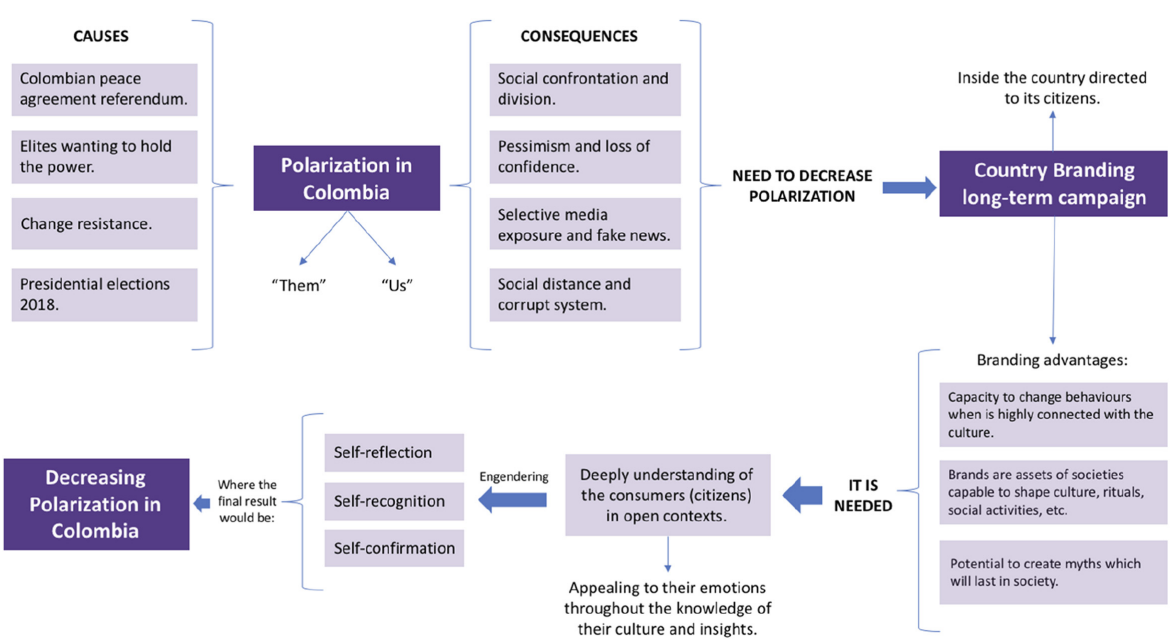


Based on the discussion of the relevant literature, Table 1 outlines the hypotheses that the research aims to test. The underpinning idea was to test the wider impact of branding on polarization (at macro-level of analysis), the impact of country branding on polarization (at meso-level of analysis) and the impact of Colombia Co country branding on polarization (at micro-level of analysis).

In order to gain a finer-grained picture of the impact of branding on polarization, the most commonly used demographic variables, namely gender, age as well as the geographical distribution of the citizens were selected as the dependent variables in line with the literature on polarization (Spohr, 2017; McCoy's et al., 2018; Somer and McCoy, 2018).

\section{Methodology}

By relying on interpretivism which involves an inductive process that provides knowledge of specific social phenomena within a particular context (Collis and Hussey, 2009) the research sought to obtain rich and relevant qualitative and quantitative data. Thus, the objective of this study was to obtain data through two types of data collection methods: A Delphi study and a survey of Colombian citizens.

\subsection{The Delphi study}

The central idea was to find experts in the following areas: politics, political communication, Colombian country branding, nation branding, and Colombian post-conflict in order to carry out several in-depth interviews concerning the topic of polarization. The interviews mostly took place in October 2018. The protocol was based on seven open one-to-one interviews where key-informants in different areas where questioned about three main topics (polarization in Colombia, nation branding and the power of branding in cultures and societies). The design of the interview protocol as well as the selection of the key-informants were highly influenced by the literature review. The interviews were recorded, transcribed, translated from Spanish into English and then manually coded and cross-analysed by the researchers. A copy of the interview protocol is enclosed in Annex 1. All the respondents

\begin{tabular}{|c|c|c|}
\hline Hypothesis & & $\begin{array}{l}\text { Level of } \\
\text { analysis }\end{array}$ \\
\hline H1 & $\begin{array}{l}\text { Branding in general can be a tool for reducing polarization of attitudes between } \\
\text { gender in Colombia }\end{array}$ & Macro-level \\
\hline $\mathrm{H} 2$ & $\begin{array}{l}\text { Country branding reduces polarization of attitudes between gender in } \\
\text { Colombia }\end{array}$ & Meso-level \\
\hline H3 & $\begin{array}{l}\text { Colombia Co country branding reduces polarization of attitudes between } \\
\text { gender in Colombia }\end{array}$ & Micro-level \\
\hline $\mathrm{H} 4$ & $\begin{array}{l}\text { Branding in general can be a tool for reducing polarization of attitudes between } \\
\text { the younger and older generations in Colombia }\end{array}$ & Macro-level \\
\hline H5 & $\begin{array}{l}\text { Country branding reduces polarization of attitudes between the younger and } \\
\text { older generations in Colombia }\end{array}$ & Meso-level \\
\hline H6 & $\begin{array}{l}\text { Colombia Co country branding reduces polarization of attitudes between the } \\
\text { younger and older generations in Colombia }\end{array}$ & Micro-level \\
\hline H7 & $\begin{array}{l}\text { Branding in general can be a tool for reducing polarization of attitudes between } \\
\text { Colombians from Bogotá and other parts of Colombia }\end{array}$ & Macro-level \\
\hline H8 & $\begin{array}{l}\text { Country branding reduces polarization of attitudes between Colombians from } \\
\text { Bogotá and other parts of Colombia }\end{array}$ & Meso-level \\
\hline H9 & $\begin{array}{l}\text { Colombia Co country branding reduces polarization of attitudes between } \\
\text { Colombians from Bogotá and other parts of Colombia }\end{array}$ & Micro-level \\
\hline
\end{tabular}

Level of

Macro-level

Meso-level

Micro-level gender in Colombia

the younger and older generations in Colombia older generations in Colombia younger and older generations in Colombia

Branding in general can be a tool for reducing polarization of attitudes between

Colombians from Bogotá and other parts of Colombia

Bogotá and other parts of Colombia

Colombians from Bogotá and other parts of Colombia

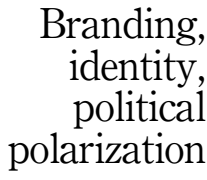

79 
IMR

38,1

80

signed a consent form by which they agreed to be named. Additionally, they were informed about the voluntary nature of their participation and that the research would have been conducted in line with the highest standards of research ethics that normally characterises academic research. A copy of the consent form has been enclosed in Annex 2.

By building on the insights from the interviews with the experts, a TV video advertisement 'Lo que nos une' ('What makes us united') was produced especially for the study in order to assess the reaction of the Colombian citizens when they were exposed to it. The advertisement was produced to a fairly high professional standard with a strong connection with the literature review with the purpose of obtaining accurate insights from the subsequent survey. The video was uploaded on Vimeo and is available here: https://vimeo. $\mathrm{com} / 282181010$. The video combines a strong narrative that is supported by powerful images that are highlighting the ways as Colombians citizens are polarized. It comprises two main parts. The first one states that the video is for the people who voted no in the referendum, but also for those who voted yes. Likewise, the advertisement claims that no matter if people are identified as part of the left-wing, the right-wing or in the centre, the message in the video is for all of them. The main idea was to convey the message that even though Colombians are different, diverse, multicultural and nowadays with opposite political mindsets, there are aspects which make them who they really are. Hence, the second part of the video was aimed at reminding them about the features of their cultural identity which make them to be all Colombians in order to generate empathy and identification with the content. One of the most important elements of the video was to present it as part of the existing brand Colombia Co, in order to analyse the suitability and potential impact of Colombia Co brand on internal nation branding. The video was preliminarily shown to the key-experts to validate its content. The expert reactions were recorded and informed a further refinement of the video content. The finalised video was then shown to the Colombian citizens who also subsequently took the survey.

\subsection{The survey}

The survey allowed the researchers to collect qualitative data and information regarding the topics well as the citizens' opinions and attitudes towards the subject. The main purpose was to obtain insights from ordinary citizens asking questions and dragging the attention to the video and its key elements. 446 participants took the survey between April 2019 and August 2019. As it was not feasible to obtain a sampling frame or survey the entire population, we opted for a non-probability sampling strategy which involved convenience and snowball sampling (Creswell and Creswell, 2018). Onwuegbuzie and Collins (2007) argue that nonprobability sampling is equally suitable for quantitative research, and that most quantitative based studies use non-random sampling strategies. However, careful consideration was given to identifying characteristics of the target population to ensure the sample would then be representative of the population (a common practice in quantitative studies relying on nonprobability sampling, see for example Donnelly et al., (2020)). This is discussed further within the quantitative analysis. The questionnaire was deliberately kept short and it included only a few key questions because the respondents also had to watch the video which lasted over two minutes. A copy of the questionnaire in English is enclosed in Annex 3.

In line with the literature on polarization, the first section of the questionnaire concerns the demographic features of the respondents, mostly age, location and gender since the idea was to assess in what ways polarization could have been curbed. The second section mostly relates to questions concerning the personal impact of the video that the respondents were made to watch. The questions addressed the feelings of the respondents stemming from watching the video, their willingness to share the video amongst friends and family, their opinion about the potential effectiveness of such a video in curbing political polarization and 
nurturing cultural identity. The key-constructs were grounded in the literature and were assessed by using a five-point Likert scale. The quantitative analysis was performed using IBM SPSS Statistics (v25) and included testing for internal reliability, summarising of the dataset with the aid of descriptive statistics, and testing of hypothesis via the use of $t$-tests in order to assess for polarization effects within the dataset.

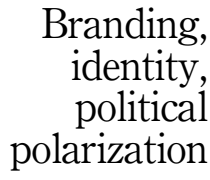

\section{Findings}

\subsection{Polarization causes in Colombia}

The initial question made was connected to the causes of polarization in Colombia. The majority of the interviewees agreed that polarization is related to the political situation that Colombia is facing in the present time. Although the interviewees agreed with this as a general cause, different explanations were provided for this phenomenon. For instance, Juanita Goebertus, lawyer, political scientist and Congresswoman in Bogota, affirmed that the rise of populist leaders is one of the main reasons for polarization since they tend to reject the past and to express that everything that is different is wrong. Thus, this idea goes in accordance with McCoy et al. (2018), who claim that populist leaders are a clear evidence of polarized societies. Furthermore, Juanita stated that:

I think that in general, the country has seen the increasing of populist leaders who do not start from the commitment to build on the built where there is a recognition that as a country we lack a lot... this tends to read society in whites and blacks where all the past is terrible, and the leader that I support is the one who is really going to be the messiah who transforms reality.

On the other hand, two of the key-informants answered that polarization is mainly due to the peace process and the elections in 2018. As a result, Colombian society lived a hard period where people took extreme sides. Mario Puerta, lawyer and adviser to the High Commissioner for Peace in Habana Dialogues, said that even though we are polarized, this is a normal consequence after having signed a peace agreement. He stated:

In a democratic country, we are giving room to an armed group determined to make a transition and to become a political group. Obviously, that group defends ideas that usually are not in the middle, but in the extreme, and when there are extreme ideas, the other side is also strengthened trying to balance those political burdens, which are also distributed again.

Lastly, Guillermo Cuellar, founder of Brújula Comunicaciones, argued that not just Colombia is polarized, this is an issue which is affecting the whole world due to the interconnectivity people have through social media. Guillermo said nowadays polarization in Colombia is likely to be produced by electoral reasons and democratic crisis. Following with this idea, Guillermo stated:

The possibility of making others feel less is a great way of doing politics because I cannot make myself look perfect, but I can show how others are imperfect. So, it has deepened the approach of citizenship to electoral politics based on the disqualification of others, in choosing who disqualified.

4.1.1 Polarization impact, solution and the role of the media. The second part of the interviews was focused on the impact of polarization and possible solutions on how to address this issue. It was found that one of the impacts that polarization has in Colombia is a reduction in the possibility of dialogue. Juanita Goebertus explained this:

Positions become so radical, we hear constantly the typical phrase of the grandmother that in the table we cannot talk about politics, because the level of fundamentalism is such in front of some and other positions, that to preserve relations, what is recommended is to avoid conversation and I think that reduces the quality of our democracy.

Thus, the risk is not just about the problems that can arise due to talks related to controversial topics, but also democracy starts to be in crisis because people cannot accept different 
IMR

38,1

opinions and this fact reduces the chance to listen and tolerate differences. Accordingly, with this idea, Ana María Ruíz, founder and director of Brujula Comunicaciones and Guillermo Cuellar, her business associate, argued that every person has an ideological bubble which everyone wants to protect, but bubbles are fragile and they are likely to be broken easily. Hence, people are so worried about protecting their own ideas that they do not want to be close to opposites. Guillermo stated:

Due to it is an ideological bubble, and the bubbles are very fragile, then any information that is contrary to my ideological bubble, I not only avoid it, but also I see it as a huge threat because it can burst my bubble. Like a fragile ideological bubble any trill that says otherwise, polarization does not occur because I ignore the issue in question, it is because I see it as a threat, it is a threat to my ideological bubble. That's why the press becomes a threat. Not only to ignore but also to consider threatening what is contrary to what I think, that sharpens the polarization.

Another consequence of polarization which Angie Palacio, journalist, digital strategist, press chief and communications director of Sergio Fajardo's campaign during the presidential elections, argued that when strong groups have the threat to lose the power they can start violent acts because they believe they have the right to kill and make people to disappear especially those ones who think differently.

José Pablo Arango, expert in country branding and General Manager of the Colombian Co country brand claimed that this peculiar dynamic that Colombia is facing related to polarization has increased the way as people are discrediting each other. Furthermore, Guillermo claimed that nowadays people have many windows to explore reality, these windows are specifically social media where individuals think that a tweet is enough to get themselves informed, and in that way people they are no longer interested in knowing more about a topic, or to explore whether some content is real or not, and in that dynamic people start conversations pushing back other people arguments. He explained:

We already have a mini window to reality, and it is undeniably real and that has deepened that confidence that I have to disqualify others based on arguments or facts that I consider real and deeply exist in my rational channels because I feel it as a fact. But, it has also made people select the reality they want to see and they access to infinite fewer realities.

4.1.2 Changing mindsets through nation branding. The third part of the interviews consisted of asking about the power of branding and communication in societies. How powerful are these tools to be able to change behaviours. In particular it was asked if they thought it was possible to change some mindsets throughout an advertising campaign done by Colombia Co. All the participants were very enthusiastic about the idea and started proposing different ways and approaches for a campaign with this purpose. A table summarizing the key-informants' ideas is presented below. It highlights the key-concepts that were included in the video advertisement that was subsequently shown to the 446 Colombian citizens (see Table 2).

Firstly, all the participants recognized that mass communication and advertising have a strong power and influence within societies. They believe that the best campaigns implemented by brands have been able to change behaviours, to educate and to generate a significant impact on people. In relation to this matter Juanita Goebertus explained:

Advertising campaigns well designed can have a very positive effect on society. I think we need a lot of publicity or campaigns that bet again on a civic culture, to stand in the shoes of the other, to understand that when I do not share the other's ideas what I have is to do is to try to recognize their points of view, that bet on a culture of dialogue, betting to reduce violence, to reduce the culture of the shortcut, betting on communicating that complying with the rules is what allows us to live together as a society, with concrete examples like if we all respect the queue. That kind of messages carried in a creative and not boring way, that really hit reflect the things we do in our own life. 
Similarly, Angie Palacio believed deeply in the power of language and communication. Angie, as a journalist, claimed that campaigns creates imaginaries, and specifically feminism campaigns have been absolutely successful because they were able to change mindsets with strong messages. She claimed that undoubtedly well-done campaigns can reach people and may start changing behaviours of societies. She brought the example of many pedagogic campaigns done in Colombia which were effective and with surprisingly good results. Likewise, Mario Puerta went aligned with Angie's opinions and ideas, he stated:

A campaign showing big differences but saying that we have to respect each other it would be a good start for a pedagogy campaign to understand each other in the difference. Although we are different, we are both fighting for the same country, to get ahead. That is, find those things that Colombians have in common, regardless of religion, region, race, that is, see that understanding in the difference, something like that would serve a lot.

Thus, the answers of the key-informants as well as their proposed approach are summarised in Table 3.

It is evident from Table 3 that there is a strong consensus among experts that an advertising campaign is able to change behaviours and societies. Half of the participants believed strongly that the best way to achieve this is through pedagogic campaigns with a very robust message in order to truly impact people and to see visible changes. On the other hand, the majority of the key-informants endorsed the idea that Colombia Co should be the official emissary of this kind of campaigns, however, this institution should be depoliticized otherwise the message might further cause polarization. Furthermore, José Pablo Arango, General Manager of Colombian Co, underlined the ideal situation should be that Colombia Co, and other country brands be doing internal campaigns, and then go abroad to sell the country because the gap between what citizens think about a country, and what foreigners think about the same country should be minimal. In his own words:

In fact, sometimes there are many people who say, if we were tremendously orthodox and let's say we had all the time and money in the world, possibly the most appropriate way would be to start a country brand process inside, looking at how to align internal issues before go out and tell any story outside. Thus, after a few years, returning to the point of closing those gaps would be easier. So, it is relevant to change the perceptions that make those gaps distant to be able to get closer and closer to reality.

\subsection{Key-informants' video validation}

After having watched the video, five of the seven key-informants felt identification, emotion, and they strongly supported the idea that a commercial like that could work in Colombia and

\begin{tabular}{lll}
$\begin{array}{l}\text { Part of the } \\
\text { video } \mathrm{AD}\end{array}$ & Key concept & Description \\
\hline First & $\begin{array}{l}\text { Aspects which make Colombians } \\
\text { citizens be polarized }\end{array}$ & $\begin{array}{l}\text { In this part of the video, it is exposed in which ways } \\
\text { Colombians are polarized and how the message } \\
\text { presented is intended to be introduced for all of them } \\
\text { The video is focused on highlight the cultural } \\
\text { identity of Colombians in order to generate positive } \\
\text { emotions in the audience }\end{array}$ \\
Third & $\begin{array}{l}\text { Explanation around what should } \\
\text { generate togetherness among } \\
\text { Colombians }\end{array}$ & $\begin{array}{l}\text { Aspirational message finalizing the end of the video, it is clear how the brand } \\
\text { video in an emotional way }\end{array}$ \\
& $\begin{array}{l}\text { Colombia Co is the emissary of the message, as part } \\
\text { of a nation branding campaign to foster cultural } \\
\text { identity and diminish polarization }\end{array}$
\end{tabular}

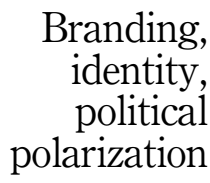


IMR
38,1

84

\begin{tabular}{|c|c|c|c|}
\hline Interviewee & Expertise & $\begin{array}{l}\text { Is it possible to change } \\
\text { mindsets through a } \\
\text { campaign? }\end{array}$ & $\begin{array}{l}\text { Approach/ } \\
\text { proposal }\end{array}$ \\
\hline Lina & PaisMarca OBS Director (country Branding & Yes & Country \\
\hline Echeverry & Colombia), lecturer, and $\mathrm{PhD}$ & & branding \\
\hline Angie Palacio & $\begin{array}{l}\text { Journalist, digital strategist, press chief and } \\
\text { communications director of Sergio Fajardo's } \\
\text { campaign (presidential elections) }\end{array}$ & Yes & $\begin{array}{l}\text { Pedagogic } \\
\text { campaign }\end{array}$ \\
\hline Mario Puerta & $\begin{array}{l}\text { Lawyer and Adviser to the High Commissioner } \\
\text { for Peace in Habana Dialogues. Nowadays } \\
\text { working as Colombian diplomat }\end{array}$ & Yes & $\begin{array}{l}\text { Pedagogic } \\
\text { campaign }\end{array}$ \\
\hline Ana Ruíz & $\begin{array}{l}\text { Political scientist and founder of Brújula } \\
\text { Comunicaciones }\end{array}$ & Yes & $\begin{array}{l}\text { Country } \\
\text { branding }\end{array}$ \\
\hline Guillermo & Industrial Designer with a Master in & Yes & Country \\
\hline Cuellar & $\begin{array}{l}\text { Communication. Founder of Brújula } \\
\text { Comunicaciones }\end{array}$ & & branding \\
\hline $\begin{array}{l}\text { José Pablo } \\
\text { Arango }\end{array}$ & $\begin{array}{l}\text { Publicist specialized in Marketing. Long } \\
\text { experience in advertising and nowadays } \\
\text { General Manager of the Colombian country } \\
\text { brand }\end{array}$ & Yes & $\begin{array}{l}\text { Country } \\
\text { branding }\end{array}$ \\
\hline $\begin{array}{l}\text { Juanita } \\
\text { Goebertus }\end{array}$ & $\begin{array}{l}\text { Lawyer, political scientist and } \\
\text { Congresswoman in Bogota, Colombia }\end{array}$ & Yes & $\begin{array}{l}\text { Pedagogic } \\
\text { campaign }\end{array}$ \\
\hline
\end{tabular}

could help to decrease polarization because it recalls the essence of being Colombian, and seek to push the citizens into 'a common ideological bubble' (as Guillermo Cuellar mentioned during his interview) in order to put together people trying to communicate that even they are all different, they have many things in common that can bring them together. In relation to video content the key-informants were particularly proactive in suggesting 'dos' and 'don'ts'. Lina Echeverry, PaisMarca OBS Director of Colombia Co, for example suggests:

I really like the content, I love the content, it's a concept of co-creation, Colombians can generate content. The only suggestions is to not lose validity and to not associate it with the Presidency. Country brand should empower the citizen, the importance of citizen participation, they should have a YouTube channel for this.

On the other hand, Mario Puerta claimed:

It is really good, it seems very cool, I think initially I would emphasize more the differences, not showing too much cliché. We could tell people that beyond differences, we are fighting for the same country. It is important to unite ourselves when we are so disunited. Maybe a group of entrepreneurs or businessman can make it real. But definitely, I think it could work.

From the point of view of José Pablo Arango there is not a better emissary that Colombia Co, he told that the message of the commercial was very suitable to the historical moment that Colombian citizens are experiencing right now. Thus, to make this idea clearer, he said:

it is clearly a message that is looking for what we were talking about a moment ago. It is a topic that if one finds a reason to invite people to see things differently, it can work and be interesting. Clearly there is an idea and a proposal, clearly there is an idea, country brand should be the most qualified issuer to make a proposal and of these, the copy is interesting, nice, is based on a discussion on some recent political campaign issues, say of generating conversations about what we agree with and it is not what we disagree with. It's a good proposal, I think it's cool.

On the contrary, a small minority of the key-informants were more pessimistic about the content of the video. They found it embedded in too many clichés both for the images and text. 
Even though they liked the aesthetic of the video in general, they were very critical of its content. For instance, Juanita Goebertus expressed some doubts about its content:

Very beautiful aesthetically, I like the images, the music. What I say to you aesthetically seems very nice... I do not know. . . sounds very empty to me. Then 'what unites us' is a bit cliché, everything of always, what unites us is the selection, it's cycling, it's the food, it's the dance, there I feel that it's a bit empty. I think that it would be necessary to take stronger steps. In other words, the victims on one side and the other, reconcile interests, environmental protection while we need economic growth for social development.

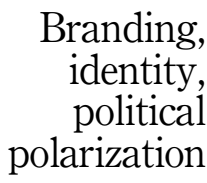

85

\subsection{Survey results}

Initially, we had 446 responses in the dataset. However, during the data cleaning process some responses with missing values were identified and were thus removed thereby ensuring the final analysis was based on complete cases only. Table 4 summarises the key information pertaining to sample demographics. Accordingly, we consider data from a sample of 426 respondents. As visible in Table 4, the gender split is almost identical thereby ensuring both male and female opinions are well (and almost equally) represented within the dataset. Majority of the respondents are aged between 21 and 40 years $(61 \%)$ whilst most respondents are from Bogotá and Medellín, respectively, followed by people from other undefined cities. The sample is fairly representative of the population where according to the latest Census in 2018 male are $49.2 \%$ of the population and female $50.8 \% .26 .7 \%$ of the population is under 15 , $67.2 \%$ is between 15 and 64 and only $6.1 \%$ is over 64 . The population mostly lives in Bogota', Cali and Medellin that are the largest cities.

After watching the video, the participants were asked if they could describe the feeling while they watched the commercial. The positive and negative feelings resulting from the process are presented via Table 5 . Interestingly, $91 \%$ of the feelings recorded were positive when they watched the commercial, with only $9 \%$ of the recorded feelings indicating negativity. The multiple response frequency output also indicated (based on percent of cases, not reported here) that the six most popular feelings were 'Amused', 'Touched', 'Hopeful', 'Proud', 'Joy' and 'Inspired'. The success of the commercial is further demonstrated with $82.9 \%$ of the respondents indicating that they would share the video with family and friends.

As the survey sets out to measure several concepts relating to branding, we tested the internal reliability of the scales by calculating Cronbach's alpha. Tavakol and Dennick (2011) asserted that the acceptable alpha value should lie between 0.70 and 0.95 . Accordingly, the constructs for Branding $(\alpha=0.70)$, Country Branding $(\alpha=0.86)$, and Colombia Co $(\alpha=0.89)$ were found to be highly reliable. Table 6 presents descriptive statistics for the Likert-scale type output. Except for responses to the question 'Colombia Co has a strong impact on society' which recorded a modal response of 3 (Neutral), all remaining questions recorded modal responses of 4, indicating that respondents 'Agreed' with the statements. In addition, the median responses to these statements were identical to the modal responses. The average responses to the individual statements indicate the sample's attitudes are either neutral or in agreement with these statements in most cases (when rounded up to the nearest whole number). It is noteworthy that prior to responding to the Colombia Co country branding questions, the respondents were asked whether they were aware of the work done by Colombia $\mathrm{Co}$, to which majority $(58 \%)$ of the sample said yes.

Next, we set out to statistically test for polarization in the sample, initially based on the sample demographics. We begin by testing the attitudes towards branding, country branding and Colombia Co concepts for statistically significant differences based on gender. For this purpose, we rely on Independent-Samples $T$ tests which are parametric. As we rely on parametric tests, it is important to determine whether the data meets the assumptions underlying these tests. First and foremost, the large sample size ensures the sampling 
IMR

38,1

\begin{tabular}{lr}
\hline Variable & $\%$ \\
\hline Gender & \\
Male & 49.8 \\
Female & 50.2 \\
Age & \\
18-20 years & 1.9 \\
21-30 years & 29.3 \\
31-40 years & 32.3 \\
41-50 years & 17.4 \\
51-60 years & 13.4 \\
More than 60 years & 5.9 \\
City & \\
Bogotá & 56.8 \\
Bucaramanga & 2.6 \\
Cali & 4.2 \\
Medellín & 0.5 \\
Other & 11.7
\end{tabular}

Table 4.

Sample demographics

Other

49.8
Table 5.

Frequencies for feelings post commercial

\begin{tabular}{lclr}
\hline Positive feelings & $N(\%)$ & Negative feelings & $N(\%)$ \\
\hline Amused & $250(14.8 \%)$ & Angry & $13(0.8 \%)$ \\
Surprise & $27(1.6 \%)$ & Sad & $23(1.4 \%)$ \\
Joy & $169(10.0 \%)$ & Bored & $19(1.1 \%)$ \\
Touched & $212(12.6 \%)$ & Confused & $21(1.2 \%)$ \\
Happy & $94(5.3 \%)$ & Tedious & $19(1.1 \%)$ \\
Hopeful & $207(12.3 \%)$ & Inadequate & $8(0.5 \%)$ \\
Inspired & $144(8.6 \%)$ & Bitter & $2(0.1 \%)$ \\
Love & $78(4.6 \%)$ & Depressed & $4(0.2 \%)$ \\
Peaceful & $80(4.8 \%)$ & Ashamed & $8(0.5 \%)$ \\
Proud & $207(12.3 \%)$ & Frustrated & $37(2.2 \%)$ \\
Satisfied & $62(3.7 \%)$ & & $154(9 \%)$ \\
Total & $1530(91 \%)$ & &
\end{tabular}

distribution of the mean is normally distributed based on the central limit theorem (Field, 2016). Secondly, the groups in this case (i.e. gender, and age and cities which are evaluated later) are independent as questions were framed to ensure that respondents belonging to one group cannot belong to another. Thirdly, we combine the Likert scales for each concept by taking the average as all scales were found to be highly reliable based on Cronbach's alpha. Therefore, we can assume the scales are interval (Boone and Boone, 2012). Table 7 reports the output from the Independent-Samples $T$-Tests. We begin the hypothesis testing process by determining whether equal variances can be assumed between gender and the attitudes towards the variables in question. The Levene's tests for equality of variances were not statistically significant and therefore we retain the null hypothesis of equality of variances across gender. The Independent-Samples $T$ tests were all statistically significant and we can conclude with $95 \%$ confidence that there exist no statistically significant differences in the respondent's attitudes towards branding $(t=-0.870, p>0.05)$, country branding $(t=-0.610$, $p>0.05)$ or Colombia Co $(t=-1.661, p>0.05)$ based on gender. This in turn indicates that branding can be a solution for removing the polarization of attitudes between genders in the 


\begin{tabular}{|c|c|c|c|c|c|}
\hline Concept & Survey question & Mean & $\begin{array}{l}\text { Standard } \\
\text { deviation }\end{array}$ & Mode & $\begin{array}{l}\text { Branding, } \\
\text { identity, }\end{array}$ \\
\hline \multirow{4}{*}{$\begin{array}{l}\text { Branding } \\
\text { (Marco-level) }\end{array}$} & Brands have a strong impact on society & 4.04 & 0.82 & 4 & \\
\hline & Mass communication can affect society & 4.40 & 0.69 & 4 & porat \\
\hline & Brands can change people point of views & 3.97 & 0.75 & 4 & \\
\hline & Brands can make people feel more united & 3.61 & 0.94 & 4 & \\
\hline \multirow{6}{*}{$\begin{array}{l}\text { Country Branding } \\
\text { (Meso-level) }\end{array}$} & Country brands have a strong impact on society & 3.76 & 0.90 & 4 & 87 \\
\hline & $\begin{array}{l}\text { Country brands can change people perceptions of a } \\
\text { country }\end{array}$ & 3.88 & 0.80 & 4 & \\
\hline & Country brands can make people feel more united & 3.69 & 0.90 & 4 & \\
\hline & Country brands can improve cultural identity & 3.91 & 0.83 & 4 & \\
\hline & $\begin{array}{l}\text { Country brand can generate positive emotions in } \\
\text { people }\end{array}$ & 4.09 & 0.70 & 4 & \\
\hline & $\begin{array}{l}\text { Country branding can attract foreign investment, } \\
\text { promote tourism and generate awareness of the } \\
\text { country }\end{array}$ & 4.21 & 0.73 & 4 & \\
\hline Colombia Country & Colombia Co has a strong impact on society & 3.21 & 0.89 & 3 & \\
\hline \multirow{5}{*}{$\begin{array}{l}\text { Branding } \\
\text { (Micro-level) }\end{array}$} & $\begin{array}{l}\text { Colombia Co can change people's perceptions of } \\
\text { Colombia }\end{array}$ & 3.76 & 0.80 & 4 & \\
\hline & Colombia Co can make its citizens feel more united & 3.54 & 0.90 & 4 & \\
\hline & Colombia Co can improve how we feel as Colombians & 3.41 & 0.94 & 4 & \\
\hline & $\begin{array}{l}\text { Colombia Co can generate positive emotions in its } \\
\text { citizens }\end{array}$ & 3.84 & 0.80 & 4 & \\
\hline & $\begin{array}{l}\text { Colombia Co-branding can attract foreign investment, } \\
\text { promote tourism and generate awareness of the } \\
\text { country }\end{array}$ & 4.00 & 0.83 & 4 & $\begin{array}{r}\text { Table } 6 . \\
\text { Descriptive statistics }\end{array}$ \\
\hline
\end{tabular}

\begin{tabular}{|c|c|c|c|c|c|}
\hline Variable & Factor & $\begin{array}{l}\text { Levene's test for equality of variances } \\
\text { ( } p \text {-value) }\end{array}$ & $t$ & $p$-value & Table 7. \\
\hline Branding (Macro-level) & Gender & $p>0.05$ & -0.870 & $p>0.05$ & Independent-Samples \\
\hline Country Branding (Meso-level) & Gender & $p>0.05$ & -0.610 & $p>0.05$ & $T$-tests for polarization \\
\hline $\begin{array}{l}\text { Colombia Co Country Branding } \\
\text { (Micro-level) }\end{array}$ & Gender & $p>0.05$ & -1.661 & $p>0.05$ & $\begin{array}{r}\text { of attitudes based on } \\
\text { Gender }\end{array}$ \\
\hline
\end{tabular}

Colombian population. Accordingly, based on the hypothesis tests we find support for $\mathrm{H} 1, \mathrm{H} 2$ and H3. A look at the average responses (not reported here, but available upon request) indicate that branding, country branding and Colombia Co have more impact on females in Colombia than males, even though we do not find any evidence of statistically significant differences between these mean responses.

Thereafter, we evaluated for significant differences in attitudes towards branding based on age. As the distribution of age was heavily skewed in the sample, we decided to group the data further as follows for the analysis. Instead of relying on six age groups as in the original data, we re-grouped them into respondents aged 18-40 years and 41 years upwards. This was done so that the attitudes of Gen-Z and Gen Y respondents could be captured within one group whilst attitudes of the older population could be captured within the other. We endorsed the assumption that given that the majority of the population in Colombia is particularly young, it was of pivotal importance to closely monitor Gen Z/Gen Y attitudes (vis-à-vis older generation) as they tend to be very active in politics given the technological 
IMR

38,1

\section{8}

advancements and access to information in the modern age that is available to them. The results are reported in Table 8. As indicated in Table 8, the sample sizes within each group are large enough for us to assume normality. Once again, the Levene's tests for equality of variances were not statistically significant (not reported, but available upon request) in all three cases and thus we retain the null hypothesis of equality of variances. In this case, we find some different, yet interesting results. Firstly, there is no evidence of a statistically significant difference between the respondent's attitudes towards the general branding questions regardless of age. Therefore, we find evidence in support of $\mathrm{H} 4$. However, there is a statistically significant difference between attitudes towards country branding and age whereby respondents who are aged 41 years upwards have comparatively less faith in country branding on average. This indicates that $\mathrm{H} 5$ remains unsupported. Nevertheless, it appears that the Colombia Co country branding indeed has a significant impact on reducing polarization of attitudes based on age in Colombia as the two-sample $T$-test results are not statistically significant and thereby indicates that there is no significant difference between the average responses of Colombians aged 18-40 years and 41 years upwards. These findings not only support $\mathrm{H6}$, but also reinforces the success of the Colombia Co campaign as was evident in the positive feelings it created within its viewers as reported in Table 5. Our findings indicate that there could be polarization of attitudes towards country branding unless the branding effort is carefully targeted to reach out to the hearts and minds of the population. Ignoring the statistical tests, the mean responses between the two groups indicate that across the board, Colombians aged 18-40 have comparatively more positive attitudes towards branding, country branding and Colombia Co country branding in relation to those aged 41 years and above.

Thereafter, we focussed our attention towards evaluating the impact of branding towards polarization based on cities in Colombia. However, as the distribution of respondents are heavily skewed when divided by city with Bogotá representing $56.8 \%$ of the sample, in order to ensure a meaningful analysis, we choose to compare the responses of people from Bogotá with the grouped responses of all other cities. The results are reported via Table 9. All assumptions underlying independent-samples $t$-tests have been met. We find no evidence of statistically significant differences between the average responses from people from Bogotá and all other cities represented within the sample in terms of their attitudes towards the

\begin{tabular}{lll}
\hline Variable & & Summary \\
\hline Branding (Macro-level) & $18-40$ years & $N=270$ \\
& 41 years upwards test statistic & $M=4.05$ \\
& & $N=156$ \\
& & $M=3.94$ \\
Country branding (Meso-level) & & $(t=1.786, p>0.05)$ \\
& $18-40$ years & $N=270$ \\
& 41 years upwards test statistic & $M=3.97$ \\
& & $N=156$ \\
Colombia Co Country branding (Micro-level) & $18-40$ years & $M=3.83$ \\
& 41 years upwards test statistic & $\left(t=2.259, p=<0.05^{*}\right)$ \\
& & $N=270$ \\
& & $N=3.66$ \\
& & $M=3.56$ \\
& & $(t=1.408, p>0.05)$
\end{tabular}

Table 8.

Results from the Independent-Samples $T$-tests for polarization of attitudes based on Age
Note(s): * Indicates results are statistically significant at the $5 \%$ significance level. $\mathrm{N}$ is the sample size and $\mathrm{M}$ is the mean 


\begin{tabular}{|c|c|c|c|}
\hline \multicolumn{2}{|l|}{ Variable } & \multirow{2}{*}{$\begin{array}{l}\text { Summary } \\
N=242\end{array}$} & \multirow{2}{*}{$\begin{array}{r}\text { Branding, } \\
\text { identity, } \\
\text { political } \\
\text { polarization }\end{array}$} \\
\hline Branding (macro-level) & $\begin{array}{l}\text { Bogotá } \\
\text { All other cities test statistic }\end{array}$ & & \\
\hline Country branding (meso-level) & $\begin{array}{l}\text { Bogotá } \\
\text { All other cities test statistic }\end{array}$ & $\begin{array}{l}N=242 \\
M=3.85 \\
N=184 \\
M=4.02 \\
\left(t=-2.931, p=<0.05^{*}\right)\end{array}$ & 89 \\
\hline Colombia Co Country Branding (micro-level) & $\begin{array}{l}\text { Bogotá } \\
\text { All other cities test statistic }\end{array}$ & $\begin{array}{l}N=242 \\
M=3.57 \\
N=184 \\
M=3.69 \\
(t=-1.722, p>0.05)\end{array}$ & $\begin{array}{r}\text { Table } 9 . \\
\text { Results from the } \\
\text { Independent-Samples } \\
T \text { tests for polarization }\end{array}$ \\
\hline \multicolumn{3}{|c|}{$\begin{array}{l}\text { Note(s): * Indicates results are statistically significant at the } 5 \% \text { significance level. } \mathrm{N} \text { is the sample size and } \mathrm{M} \text { is } \\
\text { the mean }\end{array}$} & $\begin{array}{r}\text { of attitudes bas } \\
\text { on C }\end{array}$ \\
\hline
\end{tabular}

impact of branding, thus providing evidence to support H7. However, in terms of attitudes towards country branding, our findings show no support for $\mathrm{H} 8$ as evidence for the difference in mean responses from the two-sample $t$-test is statistically significant. Interestingly, as was the case with the age factor, here too we find the Colombia Co country branding leads to reducing the polarization of attitudes of respondents from Bogotá and all other cities as the two-sample $t$-test is not statistically significant, thereby supporting H9. Yet another interesting fact is that the average responses of people from Bogotá indicate they have less faith in branding, country branding and the Colombia Co country branding in comparison to people from all other cities represented here.

Overall, our findings indicate that a carefully targeted country branding campaign such as the Colombia Co can reduce polarization within the country. However, it is noteworthy that the mean responses for the Colombia Co were lower than for those reported for branding and country branding across gender, age and cities. This further indicates that the Colombia Co should conduct more research into developing its branding so that people's attitudes could be more positively influenced through their work.

\section{Conclusion}

While country branding has been extensively investigated within the context of international business, we have a scant understanding of its domestic impact. In contrast to traditional country branding literature, this paper attempted to theoretically advance our understanding of nation branding and its effect on political polarization, as well as examining its potential influence on cultural identity. Although there is a significant number of studies on political polarization and nation branding, no attention has been devoted to country branding as a specific solution to address this issue.

The contribution of the paper is twofold. The theoretical contribution of the paper stems from its support towards the idea that internal branding can be an effective way to engage the internal stakeholders (Vasudevan, 2008; Kemp et al., 2012; Morgan et al., 2012; Che-Ha et al., 2016), to curb political polarization by fostering cultural identity by supporting Skinner and Kubacki's argument (2007). However, by doing so the analysis provides finer-grained evidence in relation to the effect of branding at macro-level, country branding at meso-level 
IMR

38,1

90

and Colombia Co country branding at micro-level across gender, age and cities. In relation to gender, the findings unequivocally indicate that branding can be a solution for removing the polarization of attitudes between genders in the Colombian population. In relation to gender, the findings indicate that branding (at macro-level), country branding (at meso-level) and Colombia Co (at micro-level) have all more impact on females in Colombia than males. As for age, there is no evidence of a statistically significant difference between the respondent's attitudes towards the general branding questions (at macro-level) regardless of age. However, there is a statistically significant difference between attitudes towards country branding (at meso-level) and age whereby respondents who are aged 41 years upwards have comparatively less faith in country branding on average. Nevertheless, it appears that the Colombia Co country branding (at micro-level) indeed has a significant impact on reducing polarization of attitudes based on age in Colombia. The findings also indicate that there could be polarization of attitudes towards country branding unless the branding effort is carefully targeted to reach out to the hearts and minds of the population. Colombians aged 18-40 have comparatively more positive attitudes towards branding (at macro-level), country branding (at meso-level) and Colombia Co country branding (at micro-level) vis-à-vis older generations. As for the geographical distribution of the citizens, the findings of people from Bogotá indicate they have less faith in branding (at macro-level), country branding (at meso-level) and the Colombia Co country branding (at micro-level) in comparison to people from all other cities represented here.

The managerial implication stemming from the findings is that a carefully targeted country branding campaign can indeed reduce polarization within a country. However, it needs to rely on rigorous research into branding in order to be effective and to reach the desired outcome. The findings have also relevant practical implications for the policy makers, whereby governments have the opportunity to implement informed and educated branding strategies not just overseas, but also to address important domestic issues. The study considers only Colombia. To fully assess the robustness of the framework it would be useful to replicate the analysis to a broader range of countries and to address a broader range of polarization issues.

\section{References}

Amine, L.S. and Chao, M.C. (2005), "Managing country image to long-term advantage: the case of Taiwan and Acer", Place Branding, Vol. 1 No. 2, pp. 187-204.

Anholt, S. (2005), "Some important distinctions in place branding", Place Branding and Public Diplomacy, Vol. 1, pp. 116-121.

Aronczyk, M. (2008), "Living the brand': nationality, globality and the identity strategies of nation branding consultants", International Journal of Communication, Vol. 2, pp. 41-65.

Askegaard, S. (2006), "Brands as a global ideoscape", in Schroeder, J. and Salzer-Mörling, M. (Eds), Brand Culture, Spon press, Routledge, pp. 91-102.

Baldassarri, D. and Bearman, P. (2007), "Dynamics of political polarization”, American Sociological Review, Vol. 72 No. 5, pp. 784-811.

Blain, C., Levy, S.E. and Ritchie, J.R.B. (2005), "Destination branding: insights and practices from destination management organizations", Journal of Travel Research, Vol. 43 No. 4, pp. 328-338.

Banerjee, S. (2008), "Strategic brand-culture fit: a conceptual framework for brand management", Journal of Brand Management, Vol. 15 No. 5, pp. 312-321.

Boone, H.N. and Boone, D.A. (2012), "Analyzing Likert data”, Journal of Extension, Vol. 50 No. 2, article nr. 2TOT2.

Cayla, J. and Arnould, E.J. (2008), "A cultural approach to branding in the global marketplace”, Journal of International Marketing, Vol. 16 No. 4, pp. 86-112. 
Chattalas, M., Kramer, T. and Takada, H. (2008), "The impact of national stereotypes on the country of origin effect: a conceptual framework", International Marketing Review, Vol. 25 No. 1, pp. 54-74.

Che-Ha, N., Nguyen, B., Yahya, W.K., Melewar, T. and Chen, Y.P. (2016), "Country branding emerging from citizens' emotions and the perceptions of competitive advantage: the case of Malaysia", Journal of Vacation Marketing, Vol. 22 No. 1, pp. 13-28.

Co, C. (2018), "Colombia country brand | official website", Colombia Country Brand, available at: http://www.colombia.co/en/ (accessed 8 May 2018).

Collis, J. and Hussey, R. (2009), Business Rresearch: A Practical Guide for Undergraduate and Postgraduate Students, Palgrave Macmillan, Basingstoke, Hampshire, New York, NY.

Cortés, J.D.M. (2018), "Comunicación política y posverdad: expresiones discursivas de la oposición al plebiscito en Colombia 2016”, Diálogos de Derecho y Política, No. 20, pp. 8-41.

Creswell, J.W. and Creswell, J.D. (2018), Research Design: Qualitative, Quantitative, and Mixed Method Approaches, 5th ed., SAGE, Los Angeles.

Dinnie, K. (2005), "Brand America: the mother of all brands", Brand America: The Mother of All Brands, Vol. 12 No. 5, pp. 405-406.

Donnelly, S., Gee, L. and Silva, E.S. (2020), "UK mid-market department stores: is fashion product assortment one key to regaining competitive advantage?", Journal of Retailing and Consumer Services, Vol. 54, p. 102043.

Duhaime, E.P. and Apfelbaum, E.P. (2017), "Can information decrease political polarization? Evidence from the U.S. Taxpayer receipt”, Social Psychological and Personality Science, Vol. 8 No. 7, pp. 736-745.

EAFIT (2017), "Polarización en Colombia: superar mitos y aceptar realidades - el Eafitense, / Edición 106 - universidad EAFIT", available at: http://www.eafit.edu.co/medios/eleafitense/106/Paginas/ polarizacion-en-colombia.aspx (accessed 12 December 2017).

Fan, Y. (2006), "Branding the nation: what is being branded?", Journal of Vacation Marketing, Vol. 12 No. 1, pp. 5-14.

Fetscherin, M. (2010), "The determinants and measurement of a country brand: the country brand strength index", International Marketing Review, Vol. 27 No. 4, pp. 466-479.

Field, A. (2016), An Adventure in Statistics: The Reality Enigma, Sage, London.

Fiske, S. and Taylor, S. (1991), Social Cognition, 2nd ed., McGraw-Hill, New York, NY.

Florek, M. (2005), "The country brand as a new challenge for Poland", Place Branding, Vol. 1 No. 2, pp. 205-214.

Gilmore, F. (2002), "A country — can it be repositioned? Spain — the success story of country branding", Journal of Brand Management, Vol. 9 No. 4, pp. 281-293.

Haley, U.C. and Low, L. (1998), "Crafted culture: governmental sculpting of modern Singapore and effects on business environments", Journal of Organizational Change Management, Vol. 11 No. 6 , pp. 530-553.

Handlin, S. (2018), "The logic of polarizing populism: state crises and polarization in South America", American Behavioral Scientist, Vol. 62 No. 1, pp. 75-91.

He, J. and Wang, C.L. (2017), "How global brands incorporating local cultural elements increase consumer purchase likelihood”, International Marketing Review, Vol. 34 No. 4, pp. 463-479.

Held, K. and Berg, N. (2015), "Liability of emergingness of emerging market multinationals in developed markets: a conceptual approach", in Experiences of Emerging Economy Firms, Palgrave Macmillan, London, pp. 6-31.

Hernández, F.C. (2018), "Posperiodismo tuitero y embustero en el ambiente electoral colombiano", ComHumanitas: Revista Científica de Comunicación, Vol. 9 No. 1, pp. 41-52.

Herstein, R. (2012), "Thin line between country, city, and region branding", Journal of Vacation Marketing, Vol. 18 No. 2, pp. 147-155. 
IMR

38,1

92

Holt, D. (2003), "What becomes an icon most?", Harvard Business Review, pp. 43-49.

JEP (2017), "ConstrucciónDePaz", available at: http://www.construcciondepaz.com/ (accessed 12 December 2017).

Kemp, E., Williams, K.H. and Bordelon, B.M. (2012), "The impact of marketing on internal stakeholders in destination branding: the case of a musical city", Journal of Vacation Marketing, Vol. 18 No. 2, pp. 121-133.

Kerrigan, F., Shivanandan, J. and Hede, A.M. (2012), "Nation branding: a critical appraisal of incredible India”, Journal of Macromarketing, Vol. 32 No. 3, pp. 319-327.

Kilduff, K. and Núñez-Tabales, J.M. (2014), "Country image management: brand Spain in the United States (US)", Regional and Sectoral Economic Studies, Vol. 14 No. 2, pp. 5-16.

Kim, Y. (2015), "Does disagreement mitigate polarization? How selective exposure and disagreement affect political polarization", Journalism and Mass Communication Quarterly, Vol. 92 No. 4, pp. 915-937.

Kotler, P., Haider, D.H. and Rein, I. (1993), Marketing Places: Attracting Investment, Industry and Tourism to Cities, States and Nations, The Free Press, New York, NY.

Kubacki, K. and Skinner, H. (2006), "Poland: exploring the relationship between national brand and national culture", Journal of Brand Management, Vol. 13 Nos 4-5, pp. 284-299.

La Nación (2018), "Paz y polarización en Colombia”, La Nación, Grupo Nación, available at: https:// www.nacion.com/opinion/editorial/paz-y-polarizacion-en-colombia/BG6CCPEQUZGZPINVOLRI WHNLAI/story/ (accessed 20 July 2018).

Lee, F.L.F. (2016), "Impact of social media on opinion polarization in varying times", Communication and the Public, Vol. 1 No. 1, pp. 56-71.

Li, D., Wang, C.L., Jiang, Y., Barnes, B.R. and Zhang, H. (2014), “The asymmetric influence of cognitive and affective country image on rational and experiential purchases", European Journal of Marketing, Vol. 48 No. 11/12, pp. 2153-2175.

Lodge, C. (2002), "Success and failure: the brand stories of two countries", Journal of Brand Management, Vol. 9 No. 4, pp. 372-384.

Martin, I.M. and Eroglu, S. (1993), "Measuring a multi-dimensional construct: country image", Journal of Business Research, Vol. 28 No. 3, pp. 191-210.

McCoy, J., Rahman, T. and Somer, M. (2018), "Polarization and the global crisis of democracy: common patterns, dynamics, and pernicious consequences for democratic polities", American Behavioral Scientist, Vol. 62 No. 1, pp. 16-42.

Miley, J. (2013), “The gathering final report”, available at: http://www.failteireland.ie/FailteIreland/ media/WebsiteStructure/Documents/eZine/TheGathering_FinalReport_JimMiley_December2013. pdf (accessed 12 December 2017).

Molano, A. and García, H. (2018), "Entrevista con Gustavo Petro: "El voto en blanco es una autoderrota", Elespectador.com, available at: https://www.elespectador.com/elecciones-2018/noticias/politica/ el-voto-en-blanco-es-una-autoderrota-gustavo-petro-articulo-793755 (accessed 25 July 2018).

Morgan, N., Hastings, E. and Pritchard, A. (2012), "Developing a new DMO marketing evaluation framework: the case of visit Wales", Journal of Vacation Marketing, Vol. 18 No. 1, pp. 73-89.

Morgan, N., Pritchard, A. and Pride, R. (Eds) (2002), Destination Branding: Creating The Unique Destination Proposition, Butterworth-Heinemann, Oxford.

Morgan, N., Pritchard, A. and Piggott, R. (2002), "New Zealand, 100\% pure. The creation of a powerful niche destination brand", Journal of Brand Management, Vol. 9 No. 4, pp. 335-354.

Morris, J.S. (2007), "Slanted objectivity? Perceived media bias, cable news exposure, and political attitudes", Social Science Quarterly, Vol. 88 No. 3, pp. 707-728.

OACP (2017), "Oficina del Alto Comisionado para la Paz", available at: http://www.altocomision adoparalapaz.gov.co/Paginas/home.aspx (accessed 12 December 2017). 
Olins, W. (2002), "Branding the nation-the historical context", Journal of Brand Management, Vol. 9 No. 4, pp. 241-248.

Onwuegbuzie, A.J. and Collins, K.M. (2007), "A typology of mixed methods sampling designs in social science research", The Qualitative Report, Vol. 12 No. 2, pp. 281-316.

Pant, D.R. (2005), "A place brand strategy for the Republic of Armenia: 'Quality of context'and 'sustainability'as competitive advantage”, Place Branding, Vol. 1 No. 3, pp. 273-282.

Pharr, J.M. (2005), "Synthesizing country-of-origin research from the last decade: is the concept still salient in an era of global brands?”, Journal of Marketing Theory and Practice, Vol. 13 No. 4, pp. 34-45.

Prelipceanu, C.M. (2015), “Country branding in a multicultural world. The case of Romania”, Synergy, Vol. 11 No. 2, pp. 152-160.

Prior, M. (2013), "Media and political polarization", Annual Review of Political Science, Vol. 16, pp. 101-127.

Rawson, E.A.G. (2007), "Perceptions of the United States of America: exploring the political brand of a nation", Place Branding and Public Diplomacy, Vol. 3 No. 3, pp. 213-221.

Roubal, O. (2017), "Sociology oOf branding: "just do it" in the "No limits" world", Communication Today, Vol. 8, p. 7.

Same, S. and Solarte-Vasquez, M.C. (2014), "Country branding and country image: insights, challenges and prospects. The case of Estonia", Baltic Journal of European Studies, Vol. 4 No. 1, pp. 137-165.

Santander, D.N., Montufar, Á.R. and Palomares, J.R. (2017), "Populismo-democracia: su relación e implicaciones como fenómeno mundial. Una perspectiva desde Colombia”, Revista Criterios, Vol. 24 No. 1, pp. 287-317.

Schneider, D. (2005), The Psychology of Stereotyping, Guilford Press, New York, NY.

Schroeder, J.E. (2009), “The cultural codes of branding”, Marketing Theory, Vol. 9 No. 1, pp. 123-126.

Semana (2017), "Polarización en Colombia, el peligro verdadero. Polarización en Colombia, el peligro verdadero", available at: http://www.semana.com/nacion/articulo/polarizacion-el-peligro-verdadero /536934 (accessed 12 December 2017).

Skinner, H. and Croft, R. (2004), "Creating the Cool: exploring the concept of national branding", International Journal of Applied Marketing, Vol. 3 No. 2, pp. 3-21.

Skinner, H. and Kubacki, K. (2007), "Unravelling the complex relationship between nationhood, national and cultural identity, and place branding", Place Branding and Public Diplomacy, Vol. 3 No. 4, pp. 305-316.

Somer, M. and McCoy, J. (2018), "Déjà vu? Polarization and endangered democracies in the 21st century", American Behavioral Scientist, Vol. 62 No. 1, pp. 3-15.

Spohr, D. (2017), "Fake news and ideological polarization: filter bubbles and selective exposure on social media”, Business Information Review, Vol. 34 No. 3, pp. 150-160.

Stavrakakis, Y. (2018), "Paradoxes of polarization: democracy's inherent division and the (anti-) populist challenge", American Behavioral Scientist, Vol. 62 No. 1, pp. 43-58.

Suarez, M. and Belk, R. (2017), "Cultural resonance of global brands in Brazilian social movements", International Marketing Review, Vol. 34 No. 4, pp. 480-497.

Tavakol, M. and Dennick, R. (2011), "Making sense of Cronbach's alpha”, International Journal of Medical Research, Vol. 2 No. 1, pp. 53-55.

Tiempo, C.E.E. (2017), "La paz no es ni puede ser una bandera de campaña santos. El Tiempo", available at: http://www.eltiempo.com/politica/gobierno/la-paz-como-bandera-para-el-2018-63420 (accessed 12 December 2017).

Vasudevan, S. (2008), "The role of internal stakeholders in destination branding: observations from Kerala Tourism”, Place Branding and Public Diplomacy, Vol. 4 No. 4, pp. 331-335.

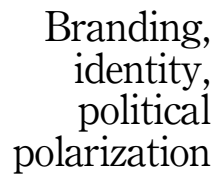

$-$ 
IMR

38,1

94

Viosca, R.C. Jr, Bergiel, B.J. and Balsmeier, P. (2004), "Effects of the electronic Nigerian money fraud on the brand equity of Nigeria and Africa", Management Research News, Vol. 27 No. 6, pp. 11-20.

Wang, C.L., Li, D., Barnes, B. and Anh, J. (2012), "Country image, product Image and consumer purchase intention: evidence from an emerging economy", International Business Review, Vol. 21 No. 6, pp. 1041-1051.

Yang, J., Rojas, H., Wojcieszak, M., Aalberg, T., Coen, S., Curran, J., Hayashi, K., Iyengar, S., Jones, P.K., Mazzoleni, G., Papathanassopoulos, S., Rhee, J.W., Rowe, D., Soroka, S. and Tiffen, R. (2016), "Why are 'others' so polarized? Perceived political polarization and media use in 10 countries", Journal of Computer-Mediated Communication, Vol. 21 No. 5, pp. 349-367. 
Annex 1

\section{Branding, identity, political \\ polarization}

(McCoy et al., 2018)

(Spohr, 2017)

(Somer and

McCoy, 2018)

95

within Colombia?

There are cases when polarization has been positive like in

Ghana and Burkina Faso. In (1)Colombia what do you think could happen? Is it going to strength democracy?

From your perspective, what do you think is the role of media on polarization? Do you have any thought about fake news and polarization?

From your discipline what do you think is the power of advertising and branding within a society?

Do you think through a communication campaign is it possible to change Colombian's minds?

Do you think an advertising campaign highlighting

Colombian culture would be capable to increase identity among citizens?

After watching this ad what is your general feeling? Do you feel identification with the content of the commercial? From your expertise is it possible to decrease polarization

Branding and its impact on cultural identity

(Holt, 2003)

(Schroeder, 2009)

(Banerjee, 2008)
Country branding within

Colombia
(Vasudevan, 2008)

(Kemp et al., 2012)

(Morgan et al.,

2012)

(Che-Ha et al.,

2016)

(Fan, 2006)

(Herstein, 2012)
Table A1. Interview protocol

\section{Annex 2}

\section{Consent form}

(1) I agree to participate in this research project. I have received sufficient information about this research project and understand my role in it. The purpose of my participation as an interviewee in this project and the future processing of my personal data has been explained to me and are is clear.

(2) My participation as an interviewee in this project is completely voluntary. There is no explicit or implicit coercion whatsoever to participate.

(3) Participation involves being interviewed by (1) researcher(s). I allow the researcher(s) to take notes during the interview. I also may allow the recording of the interview and subsequent dialogue by audio/video tape. It is clear to me that in case I do not want the interview and dialogue to be taped I am fully entitled to withdraw from participation.

(4) I have the right not to answer questions. If I feel uncomfortable in any way during the interview session, I have the right to withdraw from the interview and ask that the data collected prior to the withdrawal will be deleted.

(5) I have been given my consent that the researcher will identify me by name and by function in any reports using information obtained from this interview. Personal data will be processed in full compliance with the EU Data Protection Policy.

(6) I have carefully read and fully understood the points and statements of this form. All my questions were answered to my satisfaction, and I voluntarily agree to participate in this study. 
IMR

38,1

(7) I obtained a copy of this consent form co-signed by the interviewer.

Participant's signature and date

Researcher's signature and date

\section{Annex 3}

\section{Survey questions}

(1) What is your age?

- Under 20

- $21-30$

- $31-40$

- $41-50$

- 51-60

(2) What is your gender?

- Male

- Female

(3) In which city are you living?

- Bogotá

- Cali

- Medellín

- Cartagena

- Bucaramanga

- Other

(4) Rate the following statements on a scale 1-5

\begin{tabular}{ccccc}
\hline Strongly & & Neither disagreed or & & Strongly \\
disagree & Disagree & agree & Agree & agree \\
1 & 2 & 3 & 4 & 5 \\
\hline
\end{tabular}

General questions on branding Brands have a strong impact on society

Mass communication can affect society

Brands can change people point of views

Brands can make people feel more united 
(5) Rate the following statements on a scale 1-5

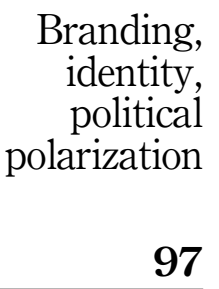

General questions on country branding Country brands have a strong impact on society

Country brands can change people perceptions of a country

Country brands can make people feel more united

Country brands can improve cultural identity

Country brand can generate positive emotions in people

Country branding can attract foreign

investment, promote tourism and to generate awareness of the country

(6) Do you know the work done by Colombia Co (the Colombia country brand)?

- Yes

- No

(7) Rate the following statements on a scale $1-5$

\begin{tabular}{|c|c|c|c|c|c|}
\hline & $\begin{array}{c}\text { Strongly } \\
\text { disagree } \\
1\end{array}$ & $\begin{array}{c}\text { Disagree } \\
2\end{array}$ & $\begin{array}{c}\text { Neither } \\
\text { disagreed or } \\
\text { agree } \\
3\end{array}$ & $\begin{array}{l}\text { Agree } \\
4\end{array}$ & $\begin{array}{l}\text { Strongly } \\
\text { agree } \\
5\end{array}$ \\
\hline $\begin{array}{l}\text { General questions on Colombia Co } \\
\text { Colombia Co has a strong impact on } \\
\text { society } \\
\text { Colombia Co can change people } \\
\text { perceptions of Columbia } \\
\text { Columbia Co can make its citizens feel } \\
\text { more united } \\
\text { Colombia Co can improve how we feel } \\
\text { Columbians } \\
\text { Colombia Co can generate positive } \\
\text { emotions in its citizens } \\
\text { Colombia Co-branding can attract } \\
\text { foreign investment, promote tourism } \\
\text { and to generate awareness of the } \\
\text { country }\end{array}$ & & & & & \\
\hline
\end{tabular}


IMR

38,1

98

(8) Could you describe the feeling while you watched the commercial? Tick all that apply

Positive feelings

Negative feelings

Amused

Surprise

Joy

Touched

Happy

Hopeful

Inspired

Love

Peaceful

Proud

Satisfied
Angry

Sad

Bored

Confused

Tedious

Inadequate

Bitter

Depressed

Ashamed

Frustrated

(9) If you have the choice, would you share the video with family and friends?

- Yes

- No

\section{Corresponding author}

Alessandra Vecchi can be contacted at: alessandra.vecchi@unibo.it

For instructions on how to order reprints of this article, please visit our website:

www.emeraldgrouppublishing.com/licensing/reprints.htm

Or contact us for further details: permissions@emeraldinsight.com 